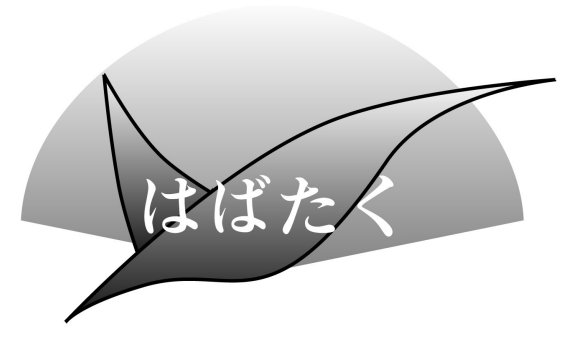

鹿児島から世界を見据えて

鹿児島大学大学院理工学研究科総合理工学専攻 ; 博士後期課程

小林領 太
私は, 鹿児島大学において学部時から物理を学び, 現在は 博士後期課程に在学し研究活動を行なっています. 4 年次の 研究室配属以来, 小山佳一, 三井好古研究室に所属し磁性材 料を研究しています。この度本稿を執筆する機会をいただき ましたので, これまでの研究の振り返りと共に, 今後の研究 活動への意気込みを述べたいと思います。

\section{2. これまでの研究}

我々の研究室では強磁場を用いた材料開発を行なっていま す. また鹿児島大学には学部 1 年次より最先端の研究に触 れる機会(サイエンスクラブ)があり, 金属材料だけでなく, 化学反応, 生物の増殖など, さまざまな現象に対する磁場効 果を評価してきました。特に学部 2,3 年次は, 鹿児島とい うことで, 焼酎酵母の菌増殖に対する磁場効果を評価し, 抑 制効果があることを見出しました. またそれらのモチベーシ ヨンを維持して, 4 年次から磁性材料の相転移に対する磁場 効果として, 強磁性 $\mathrm{Mn}-\mathrm{Al}$ に対する磁場中熱処理効果を評 価してきました．これまでに常磁性相から強磁性相への相転 移に対する磁場効果は $\mathrm{MnBi}$ などで明らかにされていまし た。一方で $\mathrm{Mn}-\mathrm{Al}$ は永久磁石として用いられていました が，ネオジム磁石の開発により現在はほとんど使われていま せん. また $\mathrm{Mn}-\mathrm{Al}$ の強磁性相は非平衡相であるために単相 合成ができないことが知られています。しかし， Mn-Alに カーボンを添加することで強磁性相の安定性を向上できるこ とがわかっています。一方でキュリー温度が $100 \mathrm{~K}$ 低下する ことが欠点として挙げられます。我々は強磁性 MnBi 合成 への磁場効果のように, 強磁性相が磁場中で安定化すること に着目してキュリー温度の低下を伴わない安定化の方法とし て磁場中熱処理を行ないました。強磁性 $\mathrm{Mn}-\mathrm{Al}$ は, 同一の 組成を有する高温相から析出することが知られています。し たがって高温相を急冷により取り出し, 磁場中熱処理を行い ました。この結果, 高温相からの相転移は促進されることお よび非平衡相に伴う常磁性平衡相への相転移は抑制されるこ とがわかりました。これらの研究成果を Mater. Trans. 58 (2017)，1511-1518に筆頭著者として投稿できました。 また これらの研究を東北大学金属材料研究所の15 Tマグネット を用いて強磁場環境下で行なったこと, 試料を作製, 解析,

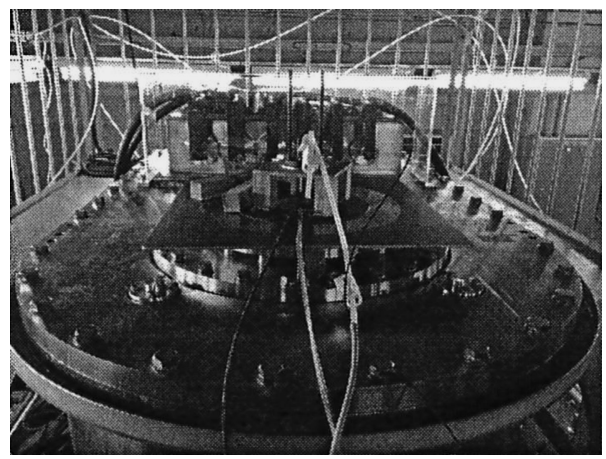

図 1 世界最高磁場で使用可能な磁場中急冷炬。（東北 大学金属材料研究所で実験）

考察という一連の流れを繰り返し, 一定の成果が得られたこ とから達成感を得ることができました．私は学部時から博士 課程への進学を希望しておりましたが，これらの経験がより 進学へのモチベーションを向上させました.さらにこれらの データを国際学会に揖いて英語で発表させていただく機会が あり,これまでの自分の世界観は狭いと感じ，もっと視野を 広げて, 鹿児島から世界をリードする研究をしたいと思い博 土後期課程に進学しました。

\section{3. 博士課程での研究}

世界最強の永久磁石として知られるネオジム磁石は日本人 が開発し, 永久磁石の研究で多くの日本人が活躍されていま す．私もそのようになりたいと思い，磁場を用いた永久磁石 の開発を行なっています．磁性体の諸特性に対する磁場効果 は多数研究されてきていますが, 磁場中での平衡状態(磁場 中平衡状態図) はほとんどの物質で明らかになっていませ ん.これまでに研究された $\mathrm{MnBi} や \mathrm{Fe}-\mathrm{C} に$ に抢いては, 強磁 性相から常磁性相への相転移温度が上昇することが明らかに なっています。しかし，これらの物質は安定相であり，その 他に非平衡相や複数の強磁性相が存在するような状態におけ る磁場中平衡状態図の作製がなく, 磁場を産業利用するには 必要です。私は博士課程において磁場中平衡状態図を明らか にしていきたいと思います. 鹿児島大学には磁場中での物質 の相状態を明らかにするために必要な磁場中急冷炉 (図 1)が あります。この急冷炉で磁場中の組織を取り出すことが可能 です.したがって, この装置を用いて, 様々な物質の磁場中 での平衡状態を明らかにしていきたいと考えています。そし て，世界をリードして新たな磁場効果や磁性材料の開発につ なげていければと思います。

\section{4. 最後に}

普段からご指導いただいている小山先生や三井先生, 共同 利用を受け入れてくださる先生をはじめ，これまでご指導く ださった先生方, 学生生活をサポートしてくれる両親, 多く の方々に支えられてきました，大変感謝して颃ります。

博士課程に進学して以降, めまぐるしく時間は経過し, 気 付けば一年が過ぎました。 博士課程ではより自主性が必要 で，やるべきことや，やりたいことがたくさん出てきまし た. 博士課程やその後の研究を見据えて, 向上心, 探究心を 忘れず，精進していきたいと思います.

(2019年 7 月 3 日受理) [doi:10.2320/materia.58.580] (連絡先 : $=890-8580$ 鹿览島市郡元 1-21-35) 